\title{
Influence of Weather Parameters on the Development of Collar Rot of Soybean caused by Sclerotium rolfsii
}

\author{
Munmi Borah ${ }^{1}$ and Hemanta Saikia ${ }^{2}$ \\ ${ }^{1}$ Department of Plant Pathology, ${ }^{2}$ Department of Agricultural Statistics, Assam Agricultural \\ University, Jorhat - 785013, India \\ *Corresponding author
}

\section{A B S T R A C T}

Keywords

Collar rot, Soybean, Sclerotium rolfsii,

Disease incidence,

Weather variables

Article Info

Accepted:

12 September 2019

Available Online:

10 October 2019
This study was undertaken during kharif season in the year 2018 at AAU, Jorhat, Assam to find out the effect of weather factors on the initiation of collar rot disease of soybean. The soybean crop was sown through field trials and the experiment was laid out in a Randomized Complete Block Design (RCBD). For data collection, a roving survey was conducted following a zig-zag sampling pattern in the field. Disease survey was conducted on weekly basis in the field to record the incidence of collar rot disease. The infected plant samples were examined in the laboratory and pathogens were confirmed using a dissecting and/or compound microscope. The percent collar rot disease incidence was recorded in each standard meteorological week from sowing to harvesting. The average weather data for each standard meteorological week relevant to the study was collected from Department of Agricultural Meteorology, AAU, Jorhat. A multiple linear regression model was developed based on the weather parameters to identify the percent disease incidence of collar rot in soybean. Thereafter, stepwise regression method was being applied to identify the influencing weather parameters and only rainfall $(p<0.05)$ was found to be statistically significant. The analysis of weather parameters with the incidence of collar rot disease of soybean will provide a base to take a preemptive decision against the disease for taking up better management practices.

\section{Introduction}

Soybean Glycine max (L.) Merill is a protein rich oilseed crop is an introduced crop in India. Soybean a rainy season crop in the rainfed agro-ecosystem of central and peninsular India (Agarwal et al., 2013) with major growing states are Madhya Pradesh,
Maharashtra, Rajasthan, Karnataka, Andhra Pradesh, and Chattisgarh (Agarwal et al., 2013). This grain legume is generally quite sensitive to photoperiod and it flowers in response to shortening of the dark period.

The crop requires 110-120 days from sowing to maturity. Soybean production requires 
aerobic soil condition. Soybean can thrive over the mean daily air temperature range of 20-30 ${ }^{\circ} \mathrm{C}$ but, low night time temperature (less than $12^{\circ} \mathrm{C}$ ) and high day time temperatures (greater than $36^{\circ} \mathrm{C}$ ) can limit production seriously.

The low productivity of soybean both at national and state level is attributed to a biotic and abiotic stresses like drought, weeds, insect pests and diseases. Assessment of many studies on crops shows that the negative impacts of climate change on crop yields at worldwide level, have been more common than positive impacts (IPCC, 2014). Food production in India is also sensitive to climate changes such as variability in monsoon rainfall and temperature changes within a season. Plant pathogens vary in the level of host specificity and in the degree of physiological interactions they have with their plant hosts, depending on their mode of infection, and climate- change factors may affect these various pathosystems differently (Runion et al., 1994; Ziska and Runion, 2007). Plant disease expression results from a three- way interaction of a susceptible host plant, a virulent pathogen and an environment suitable for disease development; referred to as the disease triangle. Changes in environmental conditions are known to exacerbate plant disease symptoms (Boyer, 1995; McElrone et al., 2001).

Among different production constraints in soybean production, the most serious being diseases and therefore identification of these diseases is vital. Anthracnose, bacterial diseases, brown spot, charcoal rot, frog eye leaf spot, Fusarium root rot, pod and stem blight, Purple seed stain and Cercospora leaf blight, Rhizoctonia aerial blight, Sclerotium blight, Seedling diseases, Soybean rust, Virus diseases and a few other diseases have been reported in India (Wrather et al., 2006).
Another report states major biotic stresses of soybean crop in India are diseases like yellow mosaic virus, rust, rhizoctonia, anthracnose, etc., and insect pests like stem fly, gridle beetle, and various defoliators (Agarwal et al., 2013). In India, the Asian soybean rust disease was first reported on soybean in 1951 (Sharma and Mehta, 1996). The occurrence of Soybean mosaic virus (SMV) in soybean grown in mid-hill condition of Meghalaya, India was confirmed by Banerjee et al., (2014). Frog eye leaf spot (Cercospora sojina), rust (Phakospora pachyrhizi), powdery mildew (Microsphaera difJusa) and purple seed stain (Cercospora kikuchii) were recorded in moderate to severe form is prevalent in North Eastern Hill region(Prasad et al.,2003).

Sclerotium blight/collar rot, caused by Sclerotium rolfsii Sacc, is a minor disease of soybean [Glycine max. (L.) Merr.], but in certain situations significant yield losses can occur in monoculture or short rotation of soybean with other crops susceptible to the pathogen (Hartman et al., 1999). In Assam and other North Eastern states collar rot caused by Sclerotium rolfsii Sacc has been found to be a major disease causing plant death and low productivity (Borah, 2019). In many instances, Sclerotium rolfsii severity is a consequence of problems such as inadequate fertility (Rodrigues et al., 2002), incorrect pH, soil compaction, poor drainage, herbicide injury (Reichard et al., 1997; Harikrishnan and Yang, 2002) and high levels of nematode infestation (Rodriguez-Kábana et al., 1994). Correcting these problems is the first step towards disease management in soybean (Hartman et al., 1999). However, other factors such as high soil moisture and temperature could be decisive to disease development (Punja, 1985). Recently, Blum and RodriguézKábana (2004) mentioned the important effect of organic matter on $S$. rolfsii development. In the present study, the effect of straw types, 
and soil temperature and moisture ranges on $S$. rolfsii sclerotia development was examined.

Gud et al., (2007) conducted research with a view to study the effect of different weather parameters viz., rainfall, humidity and temperature on the development of Alternaria leaf spot and secondly to develop forecasting model for it. The correlation studies indicated that rainfall, minimum temperature and relative humidity (RH-I andII) had a positive correlation with the disease development in all sowing times whereas the maximum temperature had a negative correlation. The results of regression equation stated that, if the rains received coupled with high humidity above $80 \%$ and temperature in the range of 21 to $32^{0} \mathrm{C}$ favors the primary infection of the crop.

Extremely limited studies have been conducted on the influence of these environmental factors like temperature, rainfall, relative humidity especially on the occurrence of collar rot in Assam (Borah, 2019) although reports revealed it as a major disease problem in North East India. Analysis of weather parameters provides a base to take preemptive decision against the disease under a given set of environmental conditions for better management practices. Keeping these points in view, the present study was undertaken to study the effect of weather variables on the initiation and development of collar rot disease, develop regression equations for predicting outbreak and determine most appropriate management measures to control collar rot disease effectively.

\section{Materials and Methods}

Field trials were conducted to find out the effect of weather parameters on collar rot in soybean during Kharif season in 2018 at Instructional cum research Farm, AAU,
Jorhat (Latitute-26 ${ }^{\circ} 45^{\prime} \mathrm{N}$, Longitue-94 ${ }^{\circ} 12^{\prime}$ E, Altitude- $87 \mathrm{~m}$ with an elevation of $116 \mathrm{~m}$ above mean sea level), Jorhat, Assam. Highly susceptible cultivar JS335 was sown in rows following recommended agronomic practices.

The experiment was laid out in a complete randomized block design (RBD).For sampling purposes, within a field a roving survey was conducted following a zig-zag sampling pattern each of the fields for recording incidence of collar rot disease (Fig 1). Disease survey was conducted on a weekly basis.

Infected plant samples were taken to the laboratory and pathogens were confirmed using a dissecting and/or compound microscope (Fig. 2). For different diseases percent incidence for soil-borne pathogens and percent disease index (PDI) for foliar pathogens following formula:

Percent Disease Incidence

$=\left(\frac{\text { Number of Plants Infected }}{\text { Total Number of Plants Observed }}\right) \times 100$

Percent collar rot disease incidence was recorded in each standard meteorological week (SMW) from sowing until harvesting (Table 1) and the average weather data for each SMW was collected from Department of Agricultural Meteorology, AAU, Jorhat, Pin785013

Also, the influence of weather parameters on collar rot disease in Soybean was examined by multiple linear regression model. In this model, percent disease incidence (PDI) of collar rot is considered as dependent variable and weather parameters are as independent variables. The model can be defined as

$Y=\beta_{0}+\beta_{1} X_{1}+\beta_{2} X_{2}+\beta_{3} X_{3}+\beta_{4} X_{4}+\beta_{5} X_{5}+\in \ldots$ 
Where $Y=$ percent disease incidence (PDI), $X_{1}$ $=$ morning temperature, $X_{2}=$ afternoon temperature, $X_{3}=$ maximum relative humidity, $X_{4}=$ minimum relative humidity, $X_{5}=$ rainfall

However, when we try to fit the model, it has been observed that none of the weather parameters are found to be significant. Also a significant high positive correlation $(r=0.996$, $\mathrm{p}=0.000<0.05)$ between morning and afternoon temperature is observed.

The collinearity diagnostics test Variance Influence Factor (VIF $=132.359>10)$ also confirms the same. It is commonly known as multicollinearity effect in the regression model. Thus, there is no point of using both the variables (i.e. Morning Temperature and Afternoon Temperature) simultaneously in the model. Due to this multicollinearity effect, the regression model defined in equation (2) couldn't be able to estimate the parameters precisely and hence none of the weather parameters are found to be significant.

Therefore, we have used a stepwise multiple linear regression method to identify the influencing weather parameters on collar rot disease in Soybean using equation (2). In stepwise regression method, the independent variables are successively adding or removing based on $t$-statistic of their estimated coefficients. After each step in which an independent variable is being added, all other variables are checked to examine if their significance has been abridged below the specified tolerance level. In any step, an independent variable is removed from the model if it is not found to be significant.

This stepwise regression method requires two significance levels. One is for adding variables in the model and another is for removing variables from the model. The cut-off probability for adding variables in the model should be less than the cut-off probability for removing variables. Thus, the whole step by step procedure doesn't get into an infinite loop.

\section{Results and Discussion}

The weekly mean values of weather parameters and percent disease incidence (PDI) are presented in Table 1. It is evident that collar rot incidence was observed from $5^{\text {th }}$ to $14^{\text {th }}$ standard meteorological week (SMW) in the cropping seasons (Table 1).

During this period, the average maximum and minimum temperature range were $21.57^{\circ} \mathrm{C}$ to $27.34^{\circ} \mathrm{C}$ and $21.11^{\circ} \mathrm{C}$ to $26.51^{\circ} \mathrm{C}$ respectively with more than 95 percent of morning relative humidity. Total rainfall of $162.33 \mathrm{~mm}$ was received which favoured the disease development and spread (Table 1).

The correlation analysis of weather parameters with a percent disease incidence of collar rot over the two seasons revealed that there is a significant positive relationship between rainfall and percent disease incidence $(\mathrm{r}=$ $0.504, p=0.033$ ). It indicates that the percent disease incidence of collar rot shall be high as rainfall increases. The other weather parameters are not found to be significant statistically towards the contribution of percent disease incidence for collar rot (c.f. Table 2).

As discussed in the methodology, a stepwise regression model was run to identify the influencing weather parameters in percent disease incidence of collar rot. It has been observed that only rainfall is found to be significant and thus the fitted regression model can be defined as

$Y=5.709+0.308 X_{5} \quad \ldots(3)$

Where $Y=$ percent disease incidence and $X_{5}=$ rainfall 
The $R^{2}$ value $0.504\left(0<R^{2}<1\right)$ based on the estimated regression equation (3) confirms that rainfall alone (Fig. 3) is influencing $50.4 \%$ towards the occurrence of percent disease incidence for collar rot. The coefficient value 0.308 implies that one percent increase in rainfall, 0.308 unit increase in percent disease incidence for collar rot. The value of the coefficient of rainfall 0.308 can vary in between 0.028 to 0.587 at $95 \%$ confidence interval.

Table.1 Effect of different environmental factors in the development of collar rot of soybean

\begin{tabular}{|c|c|c|c|c|c|c|c|}
\hline \multirow{2}{*}{$\begin{array}{c}\text { Standard } \\
\text { week }\end{array}$} & \multirow[t]{2}{*}{ Duration } & \multirow{2}{*}{$\begin{array}{c}\text { Percent } \\
\text { disease } \\
\text { incidence }\end{array}$} & \multicolumn{2}{|c|}{ Temperature $\left({ }^{\circ} \mathbf{C}\right)$} & \multicolumn{2}{|c|}{ Relative humidity (\%) } & \multirow{2}{*}{$\begin{array}{c}\text { Rainfall } \\
(\mathrm{mm})\end{array}$} \\
\hline & & & Maximum & Minimum & Morning & Evening & \\
\hline week1 & Jul.15-Jul.21 & 0 & 28.11 & 27.22 & 93.14 & 69.57 & 0.55 \\
\hline Week2 & Jul.22-Jul.28 & 0 & 26.74 & 25.97 & 93.71 & 76.71 & 7.4 \\
\hline Week 3 & Jul.29-Aug.4 & 0 & 26.34 & 25.91 & 96.42 & 78.85 & 14.12 \\
\hline Week 4 & Aug.5-Aug.11 & 0 & 27.6 & 26.57 & 27.6 & 26.57 & 10.08 \\
\hline Week 5 & Aug.12-Aug.18 & 4 & 26.91 & 26.42 & 95.85 & 74.85 & 9.38 \\
\hline Week 6 & Aug.19-Aug.25 & 10 & 27.34 & 26.51 & 98 & 84 & 13.61 \\
\hline Week 7 & Aug.25-Sept.1 & 10 & 25.74 & 25.4 & 93.28 & 76.42 & 22.75 \\
\hline Week 8 & Sept.2- Sept.8 & 20 & 25.74 & 26.2 & 97 & 75 & 7.28 \\
\hline Week 9 & Sept.9- Sept.15 & 20 & 25.74 & 26.02 & 89.42 & 70.71 & 22.65 \\
\hline Week 10 & Sept.16- Sept.22 & 20 & 26.14 & 25.31 & 93.14 & 81.42 & 0.55 \\
\hline Week 11 & $\begin{array}{l}\text { Sept.23- } \\
\text { Sept.29 }\end{array}$ & 32 & 26.45 & 25.4 & 91.42 & 70.42 & 80.04 \\
\hline Week 12 & Sept.30-Oct. 6 & 34 & 23.74 & 23.51 & 98.14 & 84.57 & 1.25 \\
\hline Week 13 & Oct.7- Oct. 13 & 10 & 22.37 & 22.05 & 96.85 & 75.57 & 1.42 \\
\hline Week 14 & Oct.14- Oct. 20 & 4 & 21.57 & 21.11 & 84.28 & 84.85 & 3.4 \\
\hline Week 15 & Oct.21- Oct. 27 & 0 & 20.85 & 20.48 & 96.42 & 58.71 & 0 \\
\hline Week 16 & Oct.28- Nov. 3 & 0 & 19.54 & 19.11 & 96 & 64.42 & 0 \\
\hline Week 17 & Nov.4-Nov.10 & 0 & 17.8 & 17.51 & 97.28 & 69.42 & 2.75 \\
\hline Week 18 & Nov.11-Nov.17 & 0 & 17.05 & 16.88 & 98.28 & 67.14 & 1.87 \\
\hline
\end{tabular}


Table.2 Correlation coefficient between weather factors and percent diseases incidence

\begin{tabular}{|c|c|c|}
\hline & $\begin{array}{c}\text { Collar } \\
\text { Rot }\end{array}$ \\
\hline \multirow{2}{*}{$\begin{array}{l}\text { Morning } \\
\text { Temperature }\end{array}$} & $\begin{array}{l}\text { Pearson } \\
\text { Correlation }\end{array}$ & .238 \\
\hline & Sig. (2-tailed) & .342 \\
\hline \multirow{2}{*}{$\begin{array}{l}\text { Afternoon } \\
\text { Temperature }\end{array}$} & $\begin{array}{l}\text { Pearson } \\
\text { Correlation }\end{array}$ & .274 \\
\hline & Sig. (2-tailed) & .272 \\
\hline \multirow{2}{*}{$\begin{array}{l}\text { Maximum } \\
\text { Relative } \\
\text { Humidity }\end{array}$} & $\begin{array}{c}\text { Pearson } \\
\text { Correlation }\end{array}$ & .074 \\
\hline & Sig. (2-tailed) & .771 \\
\hline \multirow{2}{*}{$\begin{array}{l}\text { Minimum } \\
\text { Relative } \\
\text { Humidity }\end{array}$} & $\begin{array}{c}\text { Pearson } \\
\text { Correlation }\end{array}$ & .350 \\
\hline & Sig. (2-tailed) & .154 \\
\hline \multirow[t]{2}{*}{ Rainfall } & $\begin{array}{l}\text { Pearson } \\
\text { Correlation }\end{array}$ & $.504^{*}$ \\
\hline & Sig. (2-tailed) & .033 \\
\hline
\end{tabular}

*Significant at $5 \%$ level

\begin{tabular}{|c|c|}
\hline $\begin{array}{c}\text { Fig.1 Symptoms of collar rot of } \\
\text { soybean(Sclerotiumrolfsii) in Assam }\end{array}$ & $\begin{array}{c}\text { Fig.2 Mycllial mat of Sclerotiumrolfsii } \\
\text { showing clamp connections }\end{array}$ \\
\hline 9 &
\end{tabular}


Fig.3 Effect of rainfall in the development of collar rot of soybean in Assam

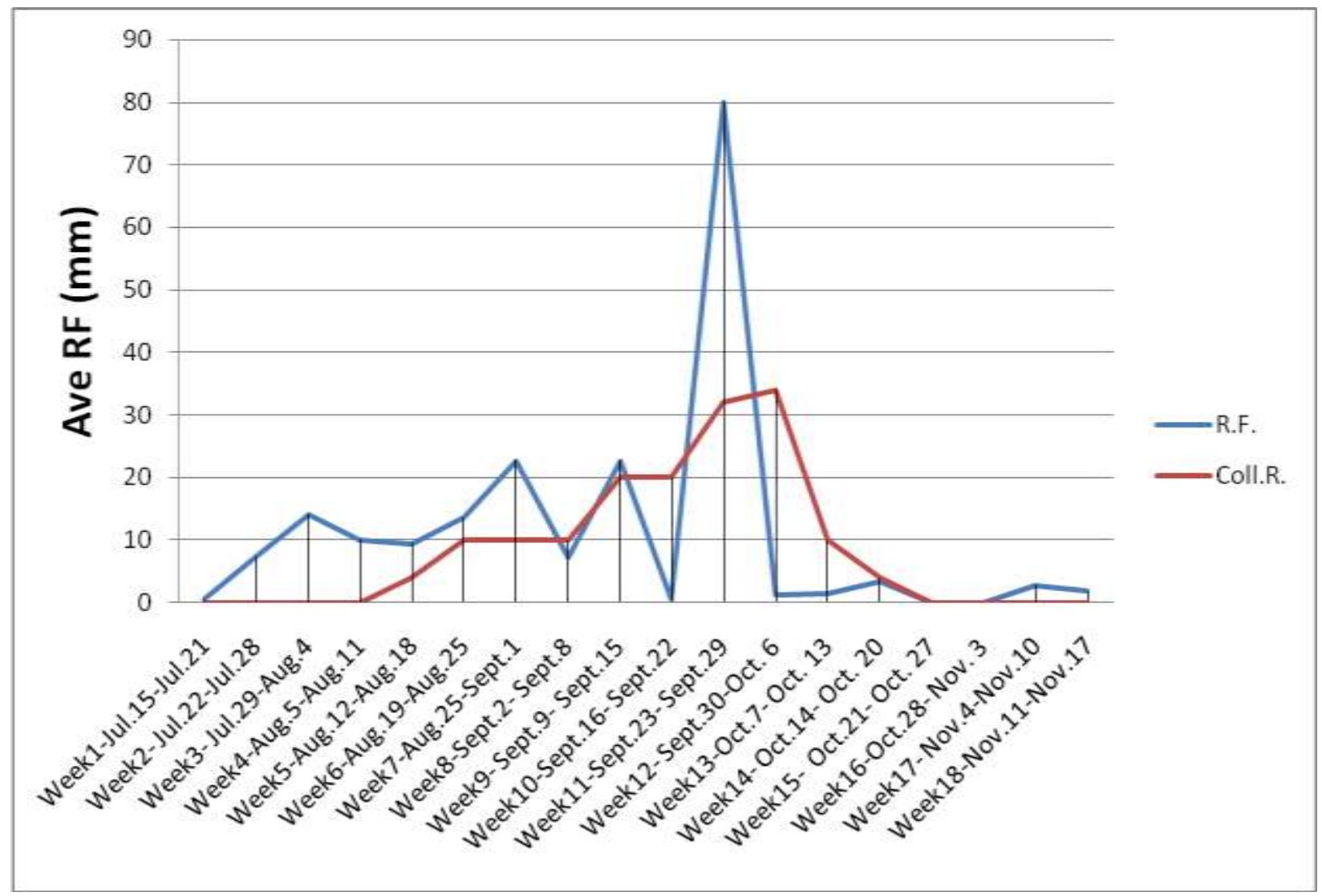

The present study results are in support of earlier findings of Punja, 1985 reported that factors such as high soil moisture and temperature could be decisive to collar rot disease development. Intermediate soil moisture level (70\% of field capacity), and temperatures ranging between $25-30^{\circ} \mathrm{C}$ favored sclerotia development. No sclerotia were formed at temperatures between $30-35^{\circ} \mathrm{C}$ (Victor et al., 2010). S. rolfsii is a serious soilborne fungal pathogen with a wide host range (Mullen, 2001) and prevalent in tropical and subtropical regions, where high temperature and moisture are sufficient to permit growth and survival of the fungal pathogen (Punja, 1985).

This study observed that all the weather parameters are not influencing the percent disease incidence of collar rot except rainfall.
Rainfall has played a significant role in the establishment of progression of collar rot in soybean. Factors that favor infection include wet soil and poorly drained or heavy clay soils. Analysis of weather parameters with the incidence of collar rot disease of soybean will provide a base to take a preemptive decision against the disease for taking up better management practices.

In Assam, the disease is highly sporadic requiring specific environmental conditions to develop. Disease incidence can vary greatly from year to year but is most damaging with prolonged wet conditions prevails. Pattern of rainfall can be a warning sign for the disease to appear and based on these disease for casting models can be developed which can helpful for taking up appropriate management practices. 
Research has shown that strategically applied foliar fungicides can be effective in reducing the level of collar rot and subsequent yield loss in soybean with a high yield potential and at high risk of developing the disease.

\section{Acknowledgment}

Authors are grateful to ICAR AICRP (All India Coordinated Research Project on Soybean

\section{References}

Agarwal, D.K., Billore, S.D. and A.N. Sharma, (2013). Soybean: Introduction, Improvement, and Utilization in India-Problems and Prospects. Agric Res 2: 293. https://doi.org/10.1007/s40003-0130088-0.

Banerjee, A., Chandra, S., Swer, E.K.P. (2014). First molecular evidence of Soybean mosaic virus (SMV) infection in soybean from India. Australasian Plant Dis. Notes 9: 150. https://doi.org/10.1007/s13314-0140150-1.

Blum, L.E.B. and Rodriguez-kabana, R.(2004). Effect of organic amendments on sclerotial germination, mycelial growth and Sclerotium rolfsiiinduced diseases. Fitopatologia Brasileira, v.29, p.66-74.

Borah Munmi. (2019). Identification of Soybean Diseases In Assam. Int J Recent Sci Res. 10(08), pp. 3415434159. DOI: http://dx.doi.org/ 10.24327/ijrsr.2019.1008.3832.

Boyer J.S. (1995). Biochemical and biophysical aspects of water deficits and the predisposition to disease. Annual Review of Phytopathology 33,251-74.
Del Ponte, E. M., Godo, C. V., Li, X. and Yang, X. B., (2006). Predicting Severity of Asian Soybean Rust Epidemics with Empirical Rainfall Models. Phytopathology., 96: 797-803.

Gud, M. A., Murumkar, D. R., Shiude, S. K. and Kadam, J. R., (2007). Corelation of weather parameter with development of leaf spot of safflower caused Alternaria carthami. All India co-ordinated research project on oil seed (safflower), Zonal Agricultural Research Station, 97 P: B. No. 207.

Harikrishnan, R.; Yang,X.B. (2002). Effects of herbicides on root rot and dampingoff caused by Rhizoctonia solaniin glyphosate- tolerant soybean. Plant Disease, v.86, p.1369-1373.

Hartman, G. L., Wang, T. C. and Tschanz, A. P. (1991). Soybean rust development and quantitative relationship between rust severity and soybean yield. Plant Disease., 75: 596-600.

Hartman, G.L.; Sinclair, J.B. and Rupe, J.C. (1999). Compendium of soybean diseases. $4^{\text {th }}$ ed. St. Paul: American Phytopathological Society,. 100p.

IPCC. (2014). Climate Change: Synthesis Report. Contribution of Working Groups I, II and III to the Fifth Assessment Report of the Intergovernmental Panel on Climate Change [Core Writing Team, R.K. Pachauri and L.A. Meyer (eds.)]. IPCC, Geneva, Switzerland, 151pp.

McElrone A.J., Sherald J.L., Forseth I.N. (2001). Effect of water stress on symptomatology and growth of Parthenocis susquinquefolia infected by Xylella fastidiosa. Plant disease 85, 1160-4.

Mullen, J. (2001). Southern blight, Southern stem blight, White mold. The Plant Health Instructor. DOI: 10.1094/PHII-2001-0104-01. 
Prasad, Santhalakshmi, Prasad, Srinivas, M. Sharma, Sangit Kumar, Y.P. and. (2003). Management of Frog Eye Leaf Spot and Rust Diseases of Soybean in NEH Region. Annals of Plant Protection Sciences 11 (2) : 292-295. 11. 292-295. 10.13140/ 2.1.2281.0248.

Punja, Z.K.(1985). The biology, ecology, and control of Sclerotium rolfsii. Annual Review of Phytopathology, v.23, p.97127.

Reichard, S.L.; Sulc, R.M.; Rhodes, L.H. and Loux, M.M. (1997). Effects of herbicides on Sclerotinia crown and stem rot of alfalfa. Plant Disease, v.81, p.787-790.

Rodrigues, F. de. A.; Carvalho, E.M. and Vale, F.X.R. (2002). do. Severidade da podridão-radicular de Rhizoctoniado feijoeiroi nfluenciadapelacalagem, e pelasfontes e doses de nitrogênio. Pesquisa Agropecuária Brasileira, v.37, p.1247-1252.

Runion, GB, Curl EA, Rogers HH, Backman PA, Rodriguez-Kabana R, Helms B.E. (1994). Effects of free air CO2 enrichment on microbial populations in the rhizosphere and phyllosphere of cotton. Agricultural and Forest Meteorology 70,117-30.
Sharma, N.D., and Mehta, S.K. (1996). Soybean rust in Madhya Pradesh. Acta Botanica Indica, 24:115-116.

Victor D.R.P, Claudine D.S.S.' CláudiaV.G., Rafael M.S., Maria C.N.O, Álvaro M.R.A.(2010). Development of Sclerotium rolfsii sclerotia on soybean, corn, and wheat straw, under different soil temperatures and moisture contents Pesquisa Agropecuária Brasileira Print version ISSN 0100204X.Pesq. agropec. bras. vol.45 no.3 Brasília Mar. 2010. http://dx.doi.org/10.1590/S0100204X2010000300014

Wrather, A., Shannon, G., Balardin, R., Carregal, L., Escobar, R., Gupta, G. K., Ma, Z., Morel, W., Ploper, D., and Tenuta, A. (2010). Effect of diseases on soybean yield in the top eight producing countries in 2006. Online. Plant Health Progress doi: 10.1094/PHP-2010- 0125-01-RS.

ZiskaLH and Runion GB (2007). Future weed, pest and disease problems for plants. In: Newton PCD, Carran RA, Edwards GR, Niklus PA, eds. Agroecosystems in a changing climate. Boca Raton, FL, USA: CRC press, 261-87.

\section{How to cite this article:}

Munmi Borah and Hemanta Saikia 2019. Influence of Weather Parameters on the Development of Collar Rot of Soybean caused by Sclerotium rolfsii. Int.J.Curr.Microbiol.App.Sci. 8(10): 1667-1675. doi: https://doi.org/10.20546/ijcmas.2019.810.194 